PRINT ISSN 1119-8362

Electronic ISSN 1119-8362
Full-text Available Online at

https://www.ajol.info/index.php/jasem

http://ww.bioline.org.br/ja
J. Appl. Sci. Environ. Manage.

Vol. 25 (7) 1201-1206 July 2021

\title{
Influence of Droughton Acacia Senegal (L.) Willd: Gum Yield within a Soil Moisture Gradient in North Eastern Nigeria
}

\author{
1,2 JIBO, AU \\ ${ }^{1}$ Mai Idris Aloom Polyechic Geidam Yobe State Nigeria \\ ${ }^{2}$ Department of Forestry and Wildlife Management, Federal University. Dutse, P.M.B. 7156, Dutse, Jigawa State, Nigeria \\ Email: jiboau@yahoo.com;Tel: +2348036212419
}

\begin{abstract}
There had been a discernible shift in climate affecting the Sahelian zone of northern Nigeria. This attribute of drought influenced the rate of gum Arabic production in the North eastern axis. Therefore, these called for the studied of the Influence of drought on Acacia senega lL.) Willd. Gum yield within a Soil moisture gradient in north eastern Nigeria. Two studied areas were purposively selected based on the availability (Gujba and Nguru). Complete Randomised Design was employed with three (3) samples examined at six (6) levels in six different tapping periods. Also, systematic line transect of $1 \mathrm{Km}$ was laid at the middle of both plantations where $1 \mathrm{~m}$ by $1 \mathrm{~m}$ transect were further laid in four transect sample plots. The soil samples were collected with the aid of soil auger at different levels $(0-25 \mathrm{~cm}, 25-50$ $\mathrm{cm}, 50-75 \mathrm{~cm}, 75-100 \mathrm{~cm}, 100-150 \mathrm{~cm}, 150-200 \mathrm{~cm}$ ).Data was subjected using analysis of variance with statistical analysis system and descriptive statistic was also employed.The results showed that mean yield of Gum Arabic is Gujba is higher than Nguru (45kg and 30kg) respectively. Furthermore, physiochemical properties showed that $\mathrm{pH}$, aluminium calcium and magnesium in both plantations were very high which is harmful for plantation development. Therefore, there is need for proper conservation and silvicultural management for both study areas.
\end{abstract}

\section{DOI:https://dx.doi.org/10.4314/jasem.v25i7.15}

Copyright: Copyright (C) 2021 Jibo. This is an open access article distributed under the Creative Commons Attribution License (CCL), which permits unrestricted use, distribution, and reproduction in any medium, provided the original work is properly cited.

Dates: Received: 10 May 2021; Revised: 28 June 2021; Accepted: 01 July 2021

Keywords: Acacia Senegal, Gum yield, soil moisture, and Influence of drought

Acacia senegal (L) Willd is a leguminous multipurpose African tree species belonging to the family Fabaceae ( Dorthe 2000; Kiondo, et al., 2014). It is a shrub or tree of small to medium size measuring up to $15 \mathrm{~m}$ in height, prickly and deciduous (Maunduet al., 1999; Booth and Wickens 1988). A. senegal are widely distributed in the arid and semi-arid regions of Nigeria, and has an enormous ecological and economic importance value for its gum, fodder and timber (Traoréet al., 2012).In Nigeria, high concentrations of cultivated and natural stands of grade one gum Arabic (A. senegal) are predominantly found in north-eastern states around latitude $10^{\circ} 30^{\circ} \mathrm{N}$ and above (Ojiekpon and Aghughu, 1997). The Nigerian production figure for 2010 was estimated at 34780 tons (UNCTAD, 2013). A ton of Nigerian raw gum Arabic is valued between USD 1550 and 1650 . World exports of crude gum Arabic originate primarily from Africa. The major producing countries are Sudan,Chad and Nigeria. The volume of international trade on gum Arabic ranges from 90,000-120,000 tons/annum (ITC, 2011). The European Union (EU) is the largest market (FAO. 2010).The precursors, enzymes and pathway of the biosynthesis of GumMaterials are not precisely known. Although, the phenomenon of Gum formation termed "Gummosi" occurs in the cavities (Gum ducts) localized in the bark of Acacia Senegal (Falu, 1982).
The cambium is involved in the formation of the special group of parenchymatious cells, which subsequently form gum duct when gummosis starts. Gum formation therefore result from the metamorphosis of the organized cell wall materials into unorganized amorphous substances, which is the gum (Brown et al, 1952). Starch is the major ingredient utilized as source for gum formation. Greater amount of gum formation is induced by harsh environmental conditions. Hence, the tapping of Gum Arabic usually commences at the end of the raining season and during on-set of hamattan period, Oct.-March (Odo, 1994).Gum Arabic production is a physiological process and as such physical factors including atmospheric temperature and soil moistures, soil physical properties and altitude, affect yield and quality (Wekesa, 2009). Gum Arabic yield is highly affected by rainfall (Ballal et al., 2005a). In a study in Sudan (North Kordofan) the authors showed that annual rainfall received in the season immediately preceding tapping strongly and positively affect the gum yield. Dione (1996) also reports a positive correlation between annual rainfall and gum production over a seven year period in the Senegalese Sahel. Oleghe and Akinnifesi (1992) showed that an adequate water supply significantly affects the production of gum in the dry season. In a similar study 
in Demokeye western Sudan, Ballal et al., (2005b) found that gum Arabic yield was positively correlated to rainfall and temperature. Furthermore, significant variation was observed in gum yield from different local provenances in Sudan (Harmand et al., 2012; Raddad and Luukkanen 2006). The aim of this study isto investigate the effect of drought stress on $A$. senegal, Gum yield within a Soil moisture testing different physiological and morphological growth parameters, and to find out if there are differences between provenances.

\section{MATERIALS AND METHODS}

Description of the study area: The investigation was carried out in two locations Nguru and Gujba provinces of Yobe state North Eastern Nigeria with a naturally occurring moisture gradient. The northern site, Nguru $\left(12.53^{\circ} \mathrm{N}, 10.28^{\circ} \mathrm{E}\right.$ alt. $\left.343 \mathrm{~m}\right)$ is classified as arid, associated with Sahel savannah and scrub vegetation zone. The climate is characterized by a distinct long dry season with no rain between October and May, and a rainy period occurring from June to September, the rainfall lasts between 80 to 100 days with annual drops ranging between $200 \mathrm{~mm}$ to $500 \mathrm{~mm}$, with average temperature during the hottest periods of the year recording over $40^{\circ} \mathrm{C}$.Soil type of the area is sandy loamy and clay, while the southern site, Gujba $\left(11.30^{\circ} \mathrm{N}, 11.56^{\circ} \mathrm{E}\right.$ alt. $\left.456 \mathrm{~m}\right)$ is classified as semi-arid, associated with Sudan savannah vegetation zone.The climate is characterized by a distinct dry season with no rain between November and April, while the rainy period occur from May to October with an annual drops ranging between $300 \mathrm{~mm}$ to $500 \mathrm{~mm}$, lasts 120 to140 days, the average temperatures during the hottest periods of the year is $35^{\circ} \mathrm{C}$. The soil is loamy sand (Jibo et al., 2018; Hess et al., 1995).

Soil sample: Soil samples were taken from a pit at each site (Nguru and Gujba) at different depths $(0-25 \mathrm{~cm}$, 25-50 cm, 50-75 cm, 75-100 cm, 100-150 cm, 150-200 cm). Undisturbed soil sample was collected by means of metal core sampler for complete soil analysis using the cylinder soil method (Blake and Hartge 1986). Soil volumetric water content was measured at $125 \mathrm{~cm}$ depth using a calibrated soil moisture probe Type PR2 (Delta $T$ Devices, Cambridge UK) with four rods of $60 \mathrm{~mm}$ length and was recorded monthly.

Sample collection: In the first year the first gum picking took place 45 days after tapping and each consecutive picking was collected after 15 days from harvest of the previous one. Tapping was carried out by specially designed tool, called a "sunki". This has a metal head fixed to a long wooden handle. The pointed end of the head was pushed tangentially into the stem to penetrate just below the bark, and then pulled up to strip a small length of bark longitudinally from the wood which involves tapping of gum Arabic trees three weeks of rain stoppage. Damage to the wood was minimal as it was tested 6 periodic levels (1st and 15th of Sept. 1st and 15th of Oct. and $1^{\text {st }}$ and 15 th of November), in each, three (3) trees will be tapped making a total number of thirty-two (32) for the season, such that eighteen trees (18) were tapped at each of the locations, namely Nguru and Gujba provinces.Humidity and Temperature were measure and store using Lascar EL-USB-2 Dew Point, Humidity, temperature Data Logger UK.

The gum from each picking weighed after drying using sensitive balance. Complete Randomized Design (CRD) was used for this study with three (3) treatments and six (6) levels making eighteen (18) samples in each plantation.

Hypotheses: The hypotheses being tested in this study will be: $\mathrm{H}_{1}$ Gum Arabic yield will be related inversely to soil moisture availability and that, $\mathrm{H}_{2}$ there will be significant variation in Gum Arabic yield from the northern and southern provenances.

Data analysis: Data was analyzed using Analysis of Variance (ANOVA) with Statistical Analysis System (All analyses were performed using the statistical software MINITAB ${ }^{\circledR}$ Release 16.12.0. and Sigma Plot ${ }^{\circledR}$ Release 12.0).) Computer package at 5\% level of significance to determine differences in the treatment effect.

\section{RESULTS AND DISCUSSION}

Physiochemical Properties: Table 1a and 1b, shows soil particle distribution and soil chemical properties at different soil depths at the Gujba and Nguru experimental sites, respectively. Generally higher clay content was found at Gujba. Sand content increased with increasing in soil depths at the Gujba site. Silt content increased with depth at the Nguru site. The study of physicochemical properties of topsoil and subsoil in Gujba and Nguru revealed a strong influence of the tree, environmental factors and litter fall production. It was discovered that the topsoil properties; sand silt, clay and soil $\mathrm{pH}$ similar within the forest reserves. There were also similarity in the other soil nutrient properties; carbon, nitrogen, phosphorus, potassium, sodium, calcium, magnesium, cation exchange capacity and organic matter arising from the effect of many factors. The physical properties were found to be normally distributed. Sand in Gujba was increased with the ranged between $44 \%-60 \%$ while in Nguru the range decreased along the profile from $81 \%-59 \%$. In Gujba and Nguru, the silt was ranged $18 \%-20 \%$ and $9 \%-21 \%$ respectively. Also, clay soil found to be higher in Gujba than Nguru with the value $37.7 \%$ $19 \%$ and $9.5 \%-19.7 \%$. 
Table 1a. Profile Characteristics and Condition on Gujba Plain

\begin{tabular}{|c|c|c|c|c|c|c|c|c|c|c|c|c|c|c|c|c|}
\hline \multirow{2}{*}{$\begin{array}{l}\text { Profile } \\
\text { Depth }(\mathrm{cm})\end{array}$} & \multicolumn{3}{|c|}{ Texture $(\%)$} & \multirow{2}{*}{$\begin{array}{l}\text { Textural } \\
\text { class }\end{array}$} & \multirow{2}{*}{$\begin{array}{l}\mathrm{pH} \\
\text { water }\end{array}$} & \multirow{2}{*}{$\begin{array}{l}\mathrm{EC} \\
(\mathrm{mS} / \mathrm{cm})\end{array}$} & \multicolumn{5}{|c|}{ Exchangeable cations (meg/100g soil) } & \multirow{2}{*}{$\begin{array}{l}\text { ECEC } \\
\%\end{array}$} & \multirow{2}{*}{ B.S } & \multirow{2}{*}{$\begin{array}{l}\text { Total } \\
\mathrm{N} \\
\end{array}$} & \multirow{2}{*}{ Org.C } & \multirow{2}{*}{$\mathrm{P}(\mu \mathrm{mg} / \mathrm{g})$} \\
\hline & sand & silt & clay & & & & $\mathrm{Ca}$ & $\mathrm{Mg}$ & $\mathrm{K}$ & $\mathrm{Na}$ & $\mathrm{H}^{+}+\mathrm{Al}^{3+}$ & & & & & \\
\hline $0-11$ & 44.3 & 18 & 37.7 & $\mathrm{CL}$ & 6.1 & 0.08 & 1.8 & 0.3 & 0,31 & 0.13 & 0.64 & 3.28 & 80.3 & 0.02 & 0.4 & 4.8 \\
\hline $11-52$ & 46.2 & 16 & 37.8 & CL & 5.3 & 0.04 & 0.7 & 0.8 & 0.21 & 0.14 & 2.55 & 4.4 & 42.1 & 0.03 & 0.6 & 2 \\
\hline $89-114$ & 52.2 & 16 & 21.8 & SCL & 6.2 & 0.05 & 2.2 & 0.9 & 0.12 & 0.21 & 0.75 & 4.18 & 82.1 & 0.02 & 1.22 & 1.22 \\
\hline $114-161$ & 60.2 & 20 & 19.8 & SCL & 6.7 & 0.06 & 2 & 0.9 & 0.15 & 0.24 & 0.6 & 3.89 & 84.6 & 0.02 & 0.76 & 2.5 \\
\hline
\end{tabular}

Table 1b. Profile Characteristics and Condition on Nguru Plain

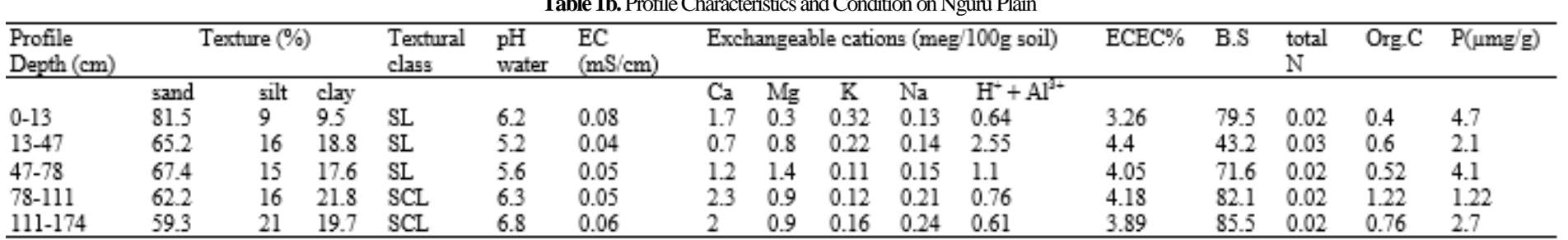

Table 2. Saturated Hydraulic Conductivity ( $\mathrm{cm} / \mathrm{hr}$ ) of Surface and Subsurface Soils of Plain sites.

\begin{tabular}{llc}
\hline Soil layer & Site & Mean Hydraulic Conductivity \\
\hline Top soil & Nguru & $2.33 \mathrm{a}$ \\
& Gujba & 1.88 \\
Sub soil $(0.75 \mathrm{~m})$ & Nguru & 2.1 \\
& Gujba & $2.68 \mathrm{a}$ \\
Sub soil $(1.5 \mathrm{~m})$ & Nguru & 1.86 \\
& Gujba & 1.26 \\
\hline
\end{tabular}

Means with the same letter subscript are not significantly different.

\begin{tabular}{|c|c|c|c|c|c|}
\hline Source & DF & SS & MS & $\mathrm{F}$ & $\mathrm{P}$ \\
\hline Provinces & 1 & 1032.12 & 1032.12 & 10.47 & 0.003 \\
\hline Treatment & 1 & 31.21 & 31.21 & 0.32 & 578 \\
\hline Interaction & 1 & 163.84 & 163.84 & 1.66 & 0.206 \\
\hline Error & 32 & 3153.47 & 98.55 & & \\
\hline Total & 35 & 4380.65 & & & \\
\hline
\end{tabular}

Post hoc analyses were performed using Tukey $95 \%$ simultaneous confidence intervals all pairwise comparisons among levels of provenance. $D F=$ degrees of freedom, Prov $=$ provenance. Variable $=$ Gum versus provinces, Treatmen 
This showed that the profile 1 to 3 were clayish in nature (Table 1a). Both provenances showed the increase with the value of $\mathrm{pH}$ ranges from $6.1-6.7 \%$ and $6.2-6.8 \%$ respectively. This implies that both provenances are acidic in nature. The soils are acidic as a typical of most soils in the savannah area derived from acid sands of Nigeria (Ubi et al., 2013).

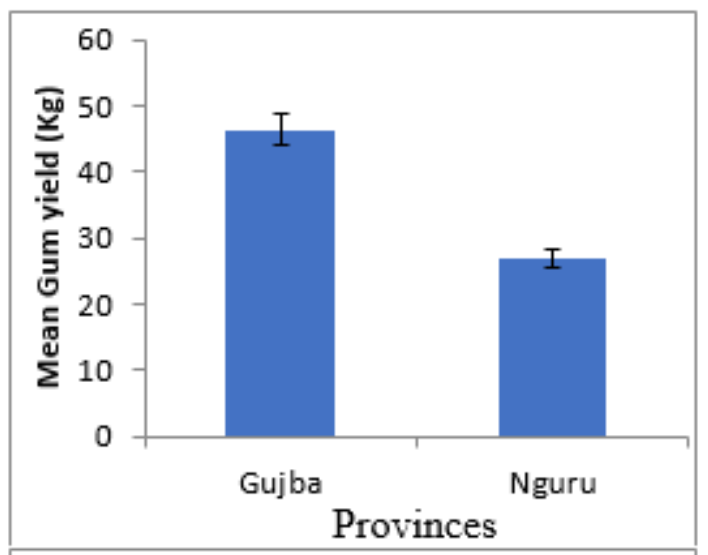

Fig 1. Mean ( \pm SE) Gum yield of A. senegal in Nguru and Gujba. There was a significant difference of $(\mathrm{P}=0.003)$ between provenances, indicating that Gujba provenances had the highest gum yield.

The higher $\mathrm{pH}$ could be attributed to the presence of pebbles and small rocks. In Gujba and Nguru, organic carbon ranged from $0.40-076 \%$ and $0.41-0.76 \%$ (Table 1a and table 1b). Both later and former had the same organic carbon status. This attributed to the rate of falling litter and decomposition wish were proved to be the equal Salami et al., (2020). The organic material serves as an energy source for soil microorganism, the bulk of which comprises fungi and bacteria (Isaac, 1993).The large variation in $\mathrm{pH}$ values of the soils is tied up with range in values of exchangeable bases and aluminums oxide. Generally, the $\mathrm{pH}$ values reflect the trend in highly weathered soils elsewhere in the Semi-deciduous ecological zones (Isaac, 1993). The data on the exchangeable calcium were normally distributed. Calcium ranged from $1.8-2.0 \mathrm{cmol}(+) / \mathrm{kg}$ and $1.7-2.0 \mathrm{~mol}(+) / \mathrm{kg}$ respectively. The mean exchangeable magnesium followed the same trend with range from $0.3-0.9 \mathrm{cmol}$ $(+) /$ kgin both reserves. Most of these values were high because they were more than $0.3 \mathrm{mg} / \mathrm{kg}$, considered average for most Nigerian soils (Sobulo, 1999; Lombin, 1973). The Available $P$ in the two provenances varies across the profiles. Upper layers had the highest percentage compared to other profiles in both reserve. Available P content is lower in all the soils across the profiles in the two provenances compare to the optimum value of between 25 and 36 ppm for tropical soils (Dean and Olson, 1965). The finding showed that total nitrogen was very small with constant value of $0.02 \mathrm{~mol}(+) / \mathrm{kg}$ except in profile 2 in both provenances. This agreed with findings of Ferreri et al., (2019) who stated that upper layer of the soil $(0-10 \mathrm{~cm})$ presented larger amount of organic matter, $\mathrm{C}, \mathrm{N}$ showing that as the depth increased the concentration of these variables interfering in the amount of the SOM

Saturated Hydrraulic Conductivity: The saturated hydraulic conductivity, Ks of Gujba ranged from 1.86 to $2.33 \mathrm{~cm} / \mathrm{hr}$. The ranges in Ks for Nguru ranged from $1.26-2.86 \mathrm{~cm} / \mathrm{hr}$ respectively (Table 2 ). The highest Ks observed in Gujba at sub soil $(0.75 \mathrm{~m})$ Thus, the Ks of Gujba was rapid at subsoil $0.75 \mathrm{~m}$ while Nguru was rapid moderately at topsoil. The test also revealed that for the top soil and subsoil at $(0.75 \mathrm{~m})$ there were significant different Gujba and Nguru while Subsoil at $1.5 \mathrm{~m}$ showed no significant different between the two sites (Table2)

Gum Production: The study has been conducted on Influence of drought on A. senegal (L.) Willd. Gum yield within a Soil moisture gradient in north eastern Nigeria. The finding showed that there was significant different between the two provenances. This is in accordance with finding of Ilu et al., (2020) that there is a significant difference in the production of Gum Arabic in Kadoma and Kwanar Duhuwa plantation. This may be due to the responses of A. senegal to drought across a moisture gradient which demonstrated that there were differences in the pattern of growth between Nguru and Gujba provenances for this species (Jibo and Barker 2020; Jibo and Barker 2019). Furthermore, there was also significant different in the interaction between the provenances and treatments. However, the treatments showed no significant different.

Conclusion: Physical and Chemical characteristics of top and subsoil indicated a strong influence of canopy, litter fall decomposition and other environmental factors. The result showed that the chemical properties were very high resulting in low fertility. These characteristics might influence the physical outlook of trees and gum yield. However, it is noteworthy that some environmental variables might have influenced the activities of the decomposer and also some soil characteristic such as high acidity directly might affect the process. Therefore, there is need for proper soil conservation and silvicultural management for both study areas.

Acknowledgements: I would like to express my appreciation to Rector Mai Idris Alooma Polytechnic, Geidam. Engr. Hussaini Abatcha Geidam, for initiating and ensuring the success of this research. Dr Salami K.D, for your technical assistance during this 
research work. This research work was funded and sponsored by Tertiary Education Trust Fund, TETFund.

\section{REFERENCES}

Allen, CD; Macalady; AK; Chenchouni; H; Bachelet; D; McDowell; N; Vennetier; M; Cobb, N (2010). A global overview of drought and heat-induced tree mortality reveals emerging climate change risks for forests. Forest Ecology and Management, 259(4), 660-684

Anderson D.M.W (1995). Gums - Ancient and modern commercial products. NFT Highlights NFTA 9501, Winrock International, Arkansas, USA

Ballal M.E El; Siddig E.A; Elfadl M.A., Luukkanen O. (2005a) Gum Arabic yield in differently managed Acacia senegal stands in western Sudan Agroforestry Forum. 63: 237-245

Ballal M.E; El Siddig E.A.; Elfadl M.A.; Luukkanen O (2005b) Relationship between environmental factors, tapping dates, tapping intensity and gum arabic yield of an Acacia senegal plantation in western Sudan. J. Arid Environ. 63: 379-389

Blake, G.R.;Hartge, K.H. (1986) Bulk density, in: A. Klute (Ed.), Methods of Soil Analysis: physical and mineralogical methods. American Society of Agronomy and Soil Science Society of America, Madison, WI, pp. 363-365.

Booth, F.E.M.;Wickens G.E. (1988) Non-timber uses of selected arid zone trees and shrubs in Africa, Food and Agriculture Organization of the UN (FAO).

Brown, H. F; Farishin, A. J; Forsaith C.C, (1952). Textbook of world

Dean, L.A.; Olson, S. R. (1965) Phosphorus. In Methods of Soil Analysis; Black, C.A. (ed.): (Agronomy Series No. 9, part 2). ASA: Madison, Wisc.Pp1035-1049.

Dione, M (1996). Recherches experimental essur legommier Acacia Senegal dans le Ferlo sénégalais. Thèse de doctorat, Université Paul Sabatier de Toulouse, France, 150 p. In; improving the traditional Acacia senegalcrop system in Sudan: the effect of tree density on water use, gum production and crop yields. Agroforestry Systems. 66: $1-11$
Dorthe J (2000). Acacia senegal (L) Willd seed leaflet. Danida Forest Seed Center. Denmark, 5: 1-2

Fakuta N. M.;Ojiekpon I. F.; Simon S. Y.; Gani, M.(2013) Genetical studies for seedling growth traits in relation to early tapping maturity of gum Arabic (Acacia Senegal (L) Willd) World J. Agric. Sci. 1 (7), pp. 248-251

Falu, A. (1982). Secretary Ducts and Lacticfer In: Plant Anatomy, Fergamon Press, New York P134

FAO, (1983). Notes on trees and shrubs in arid and semi-arid regions. EMASAR Phase II, Rome, Italy.

FAO. (2010). Guidelines on sustainable forest management in drylands of sub-Saharan Africa. Arid Zone Forests and Forestry Working Paper No. 1. Rome.

Ferrera, M. L., Andrade, N. D.V and Costa, M.C.LD. (2019). Soil fertility and Litterfall assessment in a Peri urban forest of SAO PAULO, understanding for Urban green area management, HOLOS

Harmand, J.M., Ntoupka, M., Mathieu, B., Njiti, Forkong, C, Tapsou, J.C., Bois, J., Thaler, P. and Peltier R (2012) Gum Arabic production in Acacia senegal plantations in the Sudanian zone of Cameroon: effects of climate, soil, tapping date and tree provenance. BOIS ET FORETS DES TROPIQUES 66(311):21-33.

Hess, T., Stephens, W. and Maryah, U. (1995), Rainfall trends in the north east arid zone of Nigeria 1961-1990, Agricultural and Forest Meteorology, vol. 74, no. 1, pp. 87-97.

Hines, A.S andEckman, K. (1993). Indigenous Multipurpose Trees of Tanzania: Uses and economic Benefits for people. FAO working paper 9(93): FAO, Rome.

Ilu, K. J., Salami, K.D. Muhammad. Y. K (2020) Influence of Tapping Dates On The Yield Of Acacia Senegal (L) Wild at Two Different Locations in Jigawa State, Nigeria. FUDMA Journal of Sciences (FJS) Vol. 4 No. 1, March, 2020, pp 246-249.

Isaac, T. M, (1993), Evaluation of some physical and chemical properties of soils under two agroforestry practices. A thesis submitted to the Faculty of Graduate studies, University of Ghana. 
ITC (2011). International Trade Center Geneva. Comtrade Statistic Data.

IWACO, (1985). Study of the water resources in the KomadougouYobe basin. Technical Report No. 2: Climatic analysis. IWACO B.V. Consultants, Rotterdam, unpublished.

Jamal, A; Huntsinger, L. (1993). Deterioration of a sustainable agro-silvo-pastoral system in the Sudan: the gum gardens of Kordofan. Agroforestry Systems., 23: 23-38.

Jibo, A, U., Abubakar, Z A, Salami, K.D.; Mohammed, N. Y. (2018) Diversity Assessment of Acacia senegal (L. WILLD) In two Provenaces of North Eastern Nigeria using molecular markers. Dutse Journal of Agriculture and Food security. 5 (2): 97-110.

Jibo, A.U; Barker, M.G. (2019). Effects of water deficit on growth, biomass allocation and photosynthesis of $A$. Senegal seedlings from Nguru and Gujba provinces of Yobe state, north eastern Nigeria. J. Appl. Sci. Environ. Manage. 23 (12): 2221-2229

Jibo A.U.; Barker M.G., (2020) Morphological Plasticity of Acacia Senegal (L) Willd. Seedlings within A Drought Gradient In North Eastern Nigeria J. Agric. Environ. 16 (1) 97-110.

Kiondo, F., Feyissa, T., Ndakidemi, P.A.; Seth, M. (2014). In vitro propagation of Dalbergiamelanoxylon Guill. and Perr.: a multipurpose tree. Am. J. Res. Comm. 2 (11) 181194.

Maundu, P.M., Ngugi, G.W.; Kasuye, H.C. (1999), Traditional food plants of Kenya. Nairobi, Kenya.

Odo, P. E.; P. E. Oleghe (1988). The Production and Management of Gum Arabic (Acacia Senegal) (L) Wild) in the Sudan and Sahalian Zone, of Borno State, Nigeria. J. Arid Agric. 1 (2); 257-268.

Ojiekpon, I.F.; Aghughu O. (1997). Studies on the production pattern of gum arabic in Nigeria. Paper presented at Rubber Research Institute of Nigeria Seminar series. 24th April, 1997, Iyanomo Benin City.
Oleghe P. E.; Akinnifesi F. K., (1992). Gum yield of Acacia senegalas affected by soil water potential and season of tapping. Nitrogen Fixing Tree Res. Reports, 10: 106-109.

Raddad E. Y; Luukkanen O. (2006). Adaptive genetic variation in water-use efficiency and gum yield in Acacia senegal provenances grown on clay soil in the Blue Nile region, Sudan. Forest Ecology and Management, 226: 219-229.

Salami, K. D. Ibeh, K. G.;Jibo, A. U (2020). The impact of human activities on the litter fall production, tree diversity and structural changes in the tropical forest. FUW Trend Sci. Tech. J. 5(3):705-710

Sobulo, R.A. (1999). Fertilizers analysis and Interpretation. Ipan news,(1)1 September December pp 4. Institute of Public Analyst of Nigeria Lagos.sssTechnology: Vol. 1and2, Mclarand Hill, New York, PP. 121-122.

TraoréS, Zerb L Schmidt M; Thiombiano L (2012). Acacia communities and species responses to soil and climate gradients in the Sudano-Sahelian zone of West Africa. J. Arid Environ. 87: 144-152.

Ubi, W., Ubi, M. W.; Akpanidiok, A. (2013) Effect of N. P. K 15:15:15 Fertilizer and Internal Management on the Chemical properties of Coastal plain sands of Akpabuyo. Nigeria Global J. Agric. Sci.1 (12):73-79

UNCTAD

http://www.unctad.info/en/Infocomm/AACP

Products/COMMODITY-PROFILE---GumArabic/

Wekesa, C.; Makenzi, P; Chikama, B. N;Lelon, J; K. Luvanda A. M.; Muga M. (2009) Gum Arabic yield in different varieties of Acacia senegal (L.) Willd in Kenya. Afr. J. Plant Sci. 3 (11). 263-276. 